\title{
Word N-Gram Based Advice for Word Sense Disambiguation in Telugu Natural Language Processing
}

\author{
Ratan Singh Solanki
}

\begin{abstract}
The word 'Web-based learning' sounds good but smells bad when it comes to share the study material online in context of copyright laws. The current problem is that teachers are under the impression that everything they want to share with their students online finds protection under the Doctrine of Fair use under Copyrights law but the unfortunate part is he is totally unaware about the fact that sharing the study material online may not qualify as fair use if the same is shared with students enrolled in an online course outside the campus. The need of the present paper is to make Universities and teachers working there aware about the use of Web based learning without violating the copyright laws of the land. The paper is purely conceptual and only available literatures have been taken in updating the paper following the doctrinal method of study.
\end{abstract}

Index Terms: Web-based learning, Doctrine of Fair use, Copyright laws, Universities, Teachers

\section{INTRODUCTION}

The word 'Web-based Learning' sounds good but smells bad when it comes to share the study material online.Teachers are under the impression that everything they want to share with their students online finds protection under the Doctrine of Fair use under Copyrights law which permits the limited use of copyrighted materials for educational purposes even without the permission of author or paying a licensing fee. The unfortunate part is that a teacher is totally unaware about the fact that sharing the study material online may qualify as fair use when shared with students inside the physical campus, may not qualify as fair use if the same material is shared with students enrolled in an online course outside the campus. ${ }^{1}$ In a traditional classroom, there is nothing wrong on a part of a teacher to share a limited number of copies of an article for educational purposes. But at the same time, if the same teacher teaches the same course online and thereby shares the same material to students outside his home campus online, he may be found guilty of copyright law violation. The worst part is that the poor teacher neither gets protection under Copyright laws nor gets indemnified by his employer University in case he is sued for copyright infringement. So it is the need of an hour for a teacher not only to go for Web based learning but with a fair knowledge of 'Fair use'.

\section{WHAT IS WEB-BASED LEARNING?}

Web-based learning is a hot buzz nowadays. It is a way of learning beyond the four walls of a classroom. Basically it is

Revised Manuscript Received on April 12, 2019.

Dr. Ratan Singh Solanki, Assocciate Professor, BanasthaliVidyapith,Niwai,Dist.Tonk(Raj)India. the use of computers and internet by learners to have interaction with fellow students and teacher with help of learning material. It comprises of technology which is supportive to traditional classroom learning. ${ }^{2}$

In terms of objects, web-based learning and traditional learning seems to be similar, to acquire new knowledge and skills. In both the forms, the teacher is a mentor and students do various learning activities. But the differences are quite visible when we go in depth and try to find out tools of learning, approaches to teaching, and issues pertaining to communication etc.

The most important point of distinction between webbased and traditional methods of learning lies in communication issues. Web-based learning are known for providing ways to interact with fellow students as well as Instructors. Communication is key to learn and the same is done through using tools like e-mail, mobile and online chat. Traditionally face-to-face meeting is a way of communication and interaction. Today in web-based learning, distance between the teacher and students demands for new learning and teaching approaches. The main point of difference between Web-based learning and Teacher based learning is approach. Web-based learning rests on learner-centered approach while traditional learning rests on teacher centered approach where teacher provides knowledge and students passively receives it.

In web-based learning, the teacher plays the role of motivator by encouraging and supporting students in independent and team activities. As an organizer he plans out learning activities to help and support students to learn in a better way. As a mentor he guides and tutors students through learning material and learning tasks. Students are active in their learning process. They construct their own knowledge and organize their own pattern of learning.

\section{WEB BASED LEARNING \& FAIR USE}

As far as education sector in India is concerned the ever increasing cost of education is a big factor. As far as teaching and research is concerned, as such, no distinction is made between private or non private study in reference to Copyright laws. And thus the use of literary work for purposes of education, teaching and research attracts the doctrine of fair use. This Doctrine of Fair use is one of the fundamental principles of the education system. This doctrine provides exemption to Educational institutions from copyright licensing and allows them to make copies of otherwise protected works for classroom instruction. This

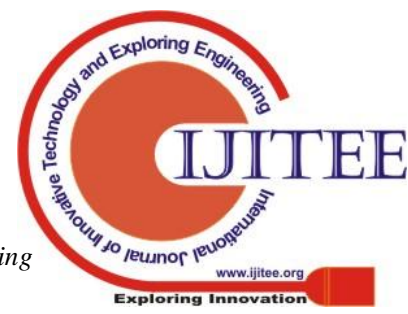


doctrine allows having use of someone else's work as an exception in some fields including education sector. In absence of this doctrine, it may amount to violation of copyright laws. Conceptually, this doctrine helps in growth of creativity, which is basic purpose of law also. This doctrine in a way is foundation pillar of Copyright Law, drawing a line between a legitimate and illegitimate use. Perhaps this is the reason why this doctrine also enshrines in TRIPS (Trade Related Aspects of Intellectual Property Rights) by virtue of Article $13 .^{3}$

In our country also, this doctrine of fair use is a fundamental part of Copyright laws but than also it is still unexplored. The Copyright Act provides for "fair dealing" or "statutory licensing". Sections $31,32-\mathrm{A}$ and 52 provide for compulsory or statutory licensing of certain literary, scientific or artistic works for instructional and certain other activities subject to reporting and royalty payment requirements.

\section{A. Fair Use}

Fair use or doctrine of fair use is one of the fundamental concept of copyright laws which opines that it is a right of public to have a free use of portions of a copyrighted material under specified circumstances. Thus one can also say that it is copying of copyrighted material done in a limited way. As far as education sector is concerned, it is fair enough for a teacher to quote a short passage to illustrate or clarify someone's observations and off course it is not a violation of fair use. Even doing the photocopy of a book for the purposes of a classroom again is fair enough. This fair use rule gives recognition to the fact that society should also be benefited by virtue of this doctrine of fair use under copy right laws to meet the ends of educational purposes. ${ }^{4}$

\section{B. Use of Copyrighted Material in Educational Institutions}

Universities and colleges are the main consumer of copyrighted materials. Whether it is a matter of translation or reproduction, or a matter of adaption or communication, they are masters of doing so. Seeing the importance of education and the needs of the students to get knowledge, information and to excel in the field of competition, this Doctrine of Fair use under Copyright law provides enough protection to educational institutions.

Section 52(1) (h) ${ }^{5}$ while adhering to Doctrine of fair use very openly says that anything which is reproduced by a student or teacher during studies in an Educational institution does not amount to infringement of copyright. This provision does not stop here only, sub clause ( $g$ ) of the same section further says that even if any matter which is not a copyrighted one, if published in a collection bonafidely for a teaching institution will also not amount to an infringement of Copyright, The present law on copyright in India do not provide expressly with the issue of photocopying of Copyrighted works for educational purpose. But the overall exception for educational sector is based on certain grounds and which is quite fair also..Education cannot be confined to the four walls of a class room, it has to come out of that so as to have interaction among students, among teachers and students and among teachers outside the class also. Again education is not a matter of a single classroom or a physical campus. Today's age is age of digitization and thus a due recognition has to be given to distance education as well as digital education.

\section{RESULTS \& DISCUSSIONS}

In spite of green pastures in Web based learning, the darker side may not be ignored. In Web based learning also, the field is not free from challenges. The design and implementation of Web-based learning environment is itself a big challenge. It also includes the challenge of catering different needs of different students because of different learning style and preferred modality. Again to complement students from face to face learning to IT based learning is not a simple task. Motivation remains the key to drive students to use a new IT based environment ${ }^{6}$

In teaching field, when we incorporate Web-based learning environments, it becomes necessary to give recognition to those factors also that may inhibit their effective use. In this IT based model of learning, it is the student who bring a great diversity of experiences and expertise to an IT based learning environment and thus Instructors/teachers should have a sense of sensitivity towards the program and towards students as well and they should adapt those teaching programs which can cater the needs of all students. Giving a proper thought on all these things are definitely going to make the learning experience of students more better .

This E learning has come out with ocean of new opportunities in education sector whereby University or school education has crossed the barrier of rigidity and now the education has become more responsive to cater the need of students. At the same time there is always a possibility that $\mathrm{E}$ - environment may not be conducive for all the students all the time because of the diversity among the students in regard to different style of learning, modality preference and their techno savy expertise along with their overall student life experience. And so, to face the challenges in the field of E-learning, future technology shall be of such kind so as to develop that kind of teaching and learning which is a student centric one.

\section{CONCLUSION}

It is the need of student as well as educational institutions in this digital age which has increased the use of the Web based learning. The blend of traditional education system with modern IT based system leaves an important and positive stamp on education of students. The more is usage of IT and more is the opportunity of Web based learning for students as well as teachers. At the same time, this Web based learning is also inviting the cases of copyright violations. The present copyright laws of India in context of fair dealing is having its own limitations and is thus confined in shell as compared to fair dealing laws of some other jurisdictions which are flexible in approach. It might be that the our law makers wanted to be more specific and certain regarding the provisions of copyright laws and that is why they opted for a conservative approach as reflected in 
Section 52 of The Indian Copyright Act.

In present paper, author finds that country like United States are more furious towards protection of Intellectual property rights because capitalism is in their blood. But the same approach cannot work in India. As enshrined in our Constitution, our roots lie in socialism. Keeping in mind the ideology of socialism, our Copyright laws also try to be fair by adopting Doctrine of fair use and thereby providing protection to Educational institutions in regarding online distribution of study material. Thus it saves the students from buying expensive books by having photo copies of that and the same is done under the name of fair dealing.

In our country, laws relating to Copyright are not merely a piece of legislation but more than that, they are laws of welfare also. And thus the author finds that the rights under copyright laws need to be in tune with social interests. And so, there is no harm relying on doctrine of Fair use ${ }^{7}$ as far as online distribution of study material is concerned within the four walls of an Education campus but at the same time, this doctrine of Fair use should not be misused by the Educational institutions as a tool of copyright infringement in age of digitalization and commercialization where they have spread out there working beyond the boundaries of physical campus by having students registered in online courses all over the world.

\section{REFERENCES}

1. Y N, Anna ,Comparing the Effectiveness of Classroom and Online Learning: Teaching Research Methods , Journal of Public Affairs Education, Vol. 19, No. 2 (SPRING 2013), pp. 199-215

2. M. Storey., B Phillips, M .Maczewski, M.Wang, Evaluating the usability of Web-based learning tools , Journal of Educational Technology \& Society, Vol. 5, No. 3, Evaluation of Learning Technologies in Higher Education (July 2002), pp. $91-100$

3. I. Hoffman., Fair Use In Online Education and Web Based Training, http://www.ivanhoffman.com/onlinefair.html

4. Photocopying of Copyrighted Works for Educational Purposes: Does it , http://www.niscair.res.in/.../rejour/.../JIPRvol\%2010-January\%202005-pp\%2021-33.htm

5. Section 52(1) in the Copyright Act, 1957 - Indian Kanoon at https://indiankanoon.org/doc/257434/

6. L Aroyo., D Darina.,The New Challenges for E-learning: The Educational Semantic Web,Journal of Educational Technology \& Society, Vol. 7, No. 4, Ontologies and the Semantic Web for E-learning (October 2004), pp. 59-69

7. R. ,Stim.What Is Fair Use? - Copyright Overview - Stanford at https://fairuse.stanford.edu > Overview Sections > Fair Use

\section{AUTHORS PROFILE}

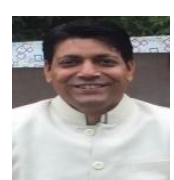
Dr.Ratan Singh Solanki.,Assocciate Professor.Faculty of Law,BanasthaliVidyapith,Niwai,Dist.Tonk(Raj) India 